\title{
PENTINGNYA KONSUMSI SAYUR DAN BUAH BAGI ANAK SEKOLAH DI SDN 082/IV SIJENJANG
}

\author{
Arnati Wulansari ${ }^{1)}$, Filius Chandra ${ }^{2)}$ \\ ${ }^{1,2}$ Program Studi Ilmu Gizi, STIKes Baiturrahim Jambi \\ email: arnatiwulansari@rocketmail.com
}

\begin{abstract}
One of the conditions in fulfilling balanced nutrition in school children is consumption of vegetables and fruit. Consumption of vegetables and fruit can protect the body and maintain weight. However, consumption of vegetables and fruits that are less can increase the risk of chronic diseases. The aim of this community service activities was to give counseling on the importance of fruit and vegetable consumption in school children at SDN 082 / IV Sijenjang. The target in this activity is that students have good knowledge about the importance of vegetables and fruit. The output of this activity is in the form of media. The activity was held for 6 months (December 2017-May 2018) at SDN 082 / IV Sijenjang. Based on the results of community service activities there was an increase in posttest value $\geq 80$ of $22.5 \%$. The increase in the results of this knowledge must be supported by the attitude to be able to consume vegetables and fruits regularly. For this reason, it is necessary to collaborate with all parties, both from schools and health centers, to continue to improve the knowledge of SDN 082 / IV Sijenjang students so that students can implement in their daily habits.
\end{abstract}

Keywords: children;consumption; vegetables and fruits

\begin{abstract}
ABSTRAK
Salah satu syarat dalam pemenuhan gizi seimbang pada anak sekolah adalah konsumsi sayur dan buah. Konsumsi sayur dan buah dapat melindungi tubuh dan menjaga berat badan. Namun konsumsi sayur dan buah yang kurang dapat meningkatkan risiko penyakit kronik. Untuk itu diperlukan kegiatan pengabdian kepada masyarakat berupa penyuluhan mengenai pentingnya konsumsi buah dan sayur pada anak sekolah di SDN 082/IV Sijenjang. Target dalam kegiatan ini adalah siswa/siswi memiliki pengetahuan baik tentang pentingnya sayur dan buah. Luaran kegiatan ini adalah berupa media. Kegiatan dilaksanakan selama 6 bulan (Desember 2017-Mei 2018) di SDN 082/IV Sijenjang. Berdasarkan hasil kegiatan pengabdian masyarakat terdapat kenaikan nilai posttest $\geq 80$ sebesar $22.5 \%$. Kenaikan hasil pengetahuan tersebut harus didukung dengan sikap untuk dapat mengonsumsi sayur dan buah secara rutin. Untuk itu diperlukan kerjasama kepada semua pihak baik dari sekolah maupun puskesmas untuk tetap terus meningkatkan pengetahuan siswa/siswi SDN 082/IV Sijenjang, agar siswa/siswi tersebut dapat mengimplementasikan dalam kebiasaan sehari-hari.
\end{abstract}

Kata Kunci: anak sekolah; konsumsi; sayur dan buah

\section{PENDAHULUAN}

Konsumsi sayur dan buah merupakan salah satu syarat dalam pemenuhan gizi seimbang pada semua umur, termasuk anak usia sekolah. Konsumsi sayur dan buah dapat melindungi tubuh dan menjaga berat badan (Mitchell, 2012). Kekurangan konsumsi sayur dan buah pada anak usia sekolah dapat meningkatkan risiko terjadinya penyakit kronik seperti jantung, diabetes, dan gangguan lainnya seperti mata, anemia, obesitas, dan konstipasi (Hung, et al. 2004). Menurut WHO (2004) kurangnya konsumsi 
sayur dan buah dapat berkontribusi penyebab kematian 2.7 juta kematian. Membiasakan anak untuk mengonsumsi sayur dan buah pada anak usia sekolah sejak dini sangat penting, karena pola diet yang diterapkan pada anak usia sekolah akan mempengaruhi ketika anak sudah dewasa (Hung, et al. 2004).

SDN 082/IV Sijenjang merupakan salah satu Sekolah Dasar Negeri yang ada di Kecamatan Jambi Timur. Letak sekolah yang merupakan perbatasan dengan Kabupaten Muara Jambi, menyebabkan sekolah ini terlihat berbeda dengan sekolah lainnya, seperti dari segi fasilitas dan bangunan yang kurang memadai. Selain itu, untuk kantin sekolah hanya menjual makanan cemilan seperti bakso dan sosis siap saji dengan tambahan saus berwarna mencolok. SDN 082/IV Sijenjang masih jarang dilakukan kegiatan pengabdian masyarakat khususnya di bidang gizi dan kesehatan, sehingga siswa/i di SDN 082/IV Sijenjang masih sedikit terpapar oleh informasi mengenai kesehatan khususnya gizi. Kegiatan berupa penyuluhan kesehatan hanya diberikan oleh puskesmas terdekat dengan frekuensi 1 bulan sekali mengenai permasalahan gigi dan mulut. Hasil survey awal terkait pengetahuan mengenai buah dan sayur ke 10 orang siswa/I SDN 082/IV Sijenjang, sekitar 6 orang diantaranya tidak menyukai sayur dan 2 orang diantaranya tidak menyukai buah dan sayur. Hal ini merupakan potensi buntuk mengembangkan kegiatan penyuluhan dan pemberian informasi mengenai gizi dan kesehatan bagi guru dan siswa/I SDN 082/IV Sijenjang. Oleh karena itu, tim pengabdian tertarik untuk melakukan kegiatan pengabdian kepada masyarakat dengan judul "Pentingnya Konsumsi Sayur dan Buah bagi Anak Sekolah" di SDN 082/IV Sijenjang.

\section{TARGET DAN LUARAN}

Target khusus dalam kegiatan ini adalah siswa/siswi memiliki pengetahuan baik setelah diberikan materi tentang pentingnya sayur dan buah. Indikator pengetahuan baik yaitu jawaban benar pada pertanyaan post test $\geq 80 \%$. Selain target khusus, kegiatan ini juga akan menghasilkan luaran yaitu media berupa leaflet, poster, dan flipchart. Selain itu penerapan konsumsi sayur dan buah serta kemampuan guru kelas dalam mentransformasikan prinsip konsumsi sayur dan buah kepada siswa/siswi secara berkesinambungan.

\section{METODE PELAKSANAAN}

Kegiatan ini dilaksanakan selama 6 bulan pada Desember 2017-Mei 2018 di SDN 082/IV Sijenjang. Sasaran pada kegiatan ini adalah siswa dan siswi kelas IV dan V SDN 082/IV Sijenjang dengan jumlah 62 orang. Kegiatan ini diawali dengan penyusunan proposal, mendesain poster, flipchart, dan leaflet konsumsi sayur dan buah, menyiapkan materi presentasi konsumsi sayur dan buah untuk disampaikan pada sasaran, dan kemudian menyiapkan lembar pre-test dan post-test.

Pelaksanaan kegiatan dilakukan dengan perkenalan tim terhadap sasaran, kemudian dilakukan penjelasan kegiatan dan pemberian lembar pre-test. Kegiatan dilanjutkan dengan melaksanakan penyampain pesan konsumsi sayur dan buah melalui media yang telah dipersiapkan seperti poster, video, flipchart, dan leaflet. Setelah itu, dilakukan diskusi dan kemudian memberikan lembar post-test sebagai feed back.

Kegiatan ini juga dilakukan monitoring dan evaluasi dengan teknik wawancara dan observasi langsung kepada sasaran. Cakupan monev dalam kegiatan ini meliputi dua aspek, yaitu perencanaan dan pelaksanaan. 


\section{HASIL DAN PEMBAHASAN}

Pengabdian masyarakat ini diikuti oleh 62 orang siswa/siswi SDN 082/IV Sijenjang dan 2 orang guru kelas. Seluruh siswa/I tersebut menghadiri kegiatan sampai selesai, sehingga capaian sasaran pada pelaksanaan kegiatan ini sebesar $100 \%$. Selain itu guru kelas mendampingi siswa/siswinya, sehingga diharapkan dapat mentransformasikan pentingnya konsumsi sayur dan buah secara berkesinambungan.

Sasaran merespon dengan baik sehingga ada feedback antara pemateri dan sasaran dalam pelaksanaan kegiatan tersebut. Berdasarkan hasil pretest diketahui bahwa sebanyak 47 siswa/I (75.8\%) memiliki nilai pretest dibawah 80 . Sebanyak 20 orang siswa/I (32.3\%) tidak mengetahui bahwa vitamin dan mineral banyak terkandung dalam buah dan sayur. Namun setelah diberikan penyuluhan tentang buah dan sayur, sasaran yang menjawab salah pada pertanyaan tersebut menurun yaitu sebesar $16 \%$.

Tabel 1 Hasil pretest dan posttest

\begin{tabular}{lcccc}
\hline & \multicolumn{2}{c}{ Nilai Pre-test } & \multicolumn{2}{c}{$\begin{array}{c}\text { Nilai Post- } \\
\text { test }\end{array}$} \\
Nilai & n & \% & n & \% \\
\hline$>=80$ & 15 & 24.2 & 29 & 46.7 \\
$<80$ & 47 & 75.8 & 33 & 53.3 \\
total & 62 & 100 & 62 & 100 \\
\hline
\end{tabular}

Kebiasaan jajan sasaran lebih kepada makanan siap saji seperti bakso, telur gulung, nasi goreng, dan lain-lain. Untuk buah dan sayur lebih sering dikonsumsi di rumah dan frekuensinya jarang. Salah satu faktor yang mempengaruhinya adalah pengetahuan gizi anak sekolah yang masih kurang (46.8\%). Menurut hasil penelitian Bourdeaudhuij et al. (2009) menemukan bahwa pengetahuan gizi anak usia sekolah mengenai konsumsi buah dan sayur berhubungan signifikan dengan konsumsi buah dan sayur. Pengetahuan tentang buah dan sayur berbanding lurus dengan konsumsi buah dan sayur (Kristjandottir et al. 2006). Namun menurut Vereecken et al. (2004) menyatakan bahwa ketika anak memasuki usia sekolah, anak mulai mendapat pengaruh dari lingkungan luar, seperti guru, teman sebaya dan satu grup, dan pengaruh media. Pengaruh tersebut ada yang berpengaruh positif dan negative terhadap konsumsi sayur dan buah yang berasal dari pengetahuan dan sikap.

Berdasarkan hasil post-test diperoleh kenaikan sebesar $22.5 \%$ pada nilai $\geq 80$. Namun hal ini masih belum diikuti oleh sikap siswa/siswi SDN 082/IV Sijenjang untuk dapat mengonsumsi sayur dan buah secara rutin. Hal ini dikarenakan masih terdapat siswa/siswi yang tidak menyukai sayur terutama sayur dengan rasa yang pahit dan buah dengan struktur yang lembek seperti alpukat. Hasil penelitian mengenai konsumsi sayur dan buah pada anak sekolah di Bogor menyebutkan bahwa tidak adanya hubungan antara konsumsi sayur dan buah pada subjek terhadap sikap (Mohammad dan Madanijah 2015). Hal ini berarti bahwa sikap yang baik belum menentukan baiknya konsumsi sayur dan buah.

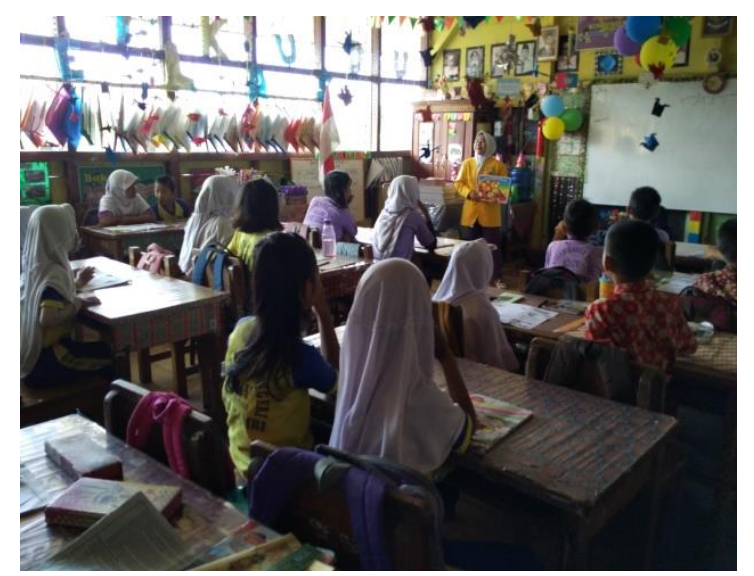

Gambar 1. Penjelasan Materi 


\section{KESIMPULAN DAN SARAN}

\section{Kesimpulan}

Berdasarkan kegiatan pengabdian kepada masyarakat yang telah dilaksanakan di SDN 082/IV Sijenjang dapat disimpulkan bahwa sebanyak $100 \%$ siswa/I menghadiri kegiatan tersebut hingga selesai. Pada hasil pre dan post test terdapat perubahan pengetahuan yang baik pada sasaran. Sasaran berkomitmen untuk mengonsumsi sayur dan buah setiap hari.

\section{Saran}

Diharapkan kepada pihak sekolah untuk menyediakan buah segar dan sayur pada jajanan yang dijual di kantin sekolah. Selain itu, diharapkan juga pihak sekolah untuk terus memantau kebiasaan konsumsi sayur dan buah. Perlu adanya kerja sama dari pihak sekolah, puskesmas, dan pendidikan kesehatan setempat dalam penyediaan sarana informasi seperti poster, leaflet, dan video untuk menunjang penyampaian informasi tentang kesehatan di lingkungan sekolah.

\section{UCAPAN TERIMAKASIH}

Penulis mengucapkan terima kasih kepada STIKES Baiturrahim Jambi yang telah mendanai kegiatan ini sehingga kegiatan ini dapat berjalan dengan lancar. Penulis juga mengucapkan terima kasih kepada Kepala sekolah SDN 082/IV Sijenjang yang telah mengizinkan penulis dan tim untuk melakukan kegiatan pengabdian kepada masyarakat di SDN 082/IV Sijenjang.

\section{DAFTAR PUSTAKA}

Bourdeaudhuij ID, Velde St, Brug J, Due P, Wind M, Sandvik C, Maes L, Wolf A, Rodrigo CP, Yngve A et al. 2008. Personal, social, and environmental predictors of daily fruit and vegetable intake in 11 year old children in nine European countries. Eur J Clin Nutr 62:834841.

Hung HC, Joshipura KJ, Jiang R, Hu FB, Hunter D, Smith-Warner Sa, Colditz GA, Rosner B, Spiegelman D, Willet WC. 2004. Fruit and vegetable intake and risk of major chronic disease. J Natl cancer inst. 96 (21) : 1577-84

Kristjandottir AG, Thorsdottir I, Bourdeaudhuij ID, Due P, Wind M, Klepp KI. 2006. Determinant of fruit and vegetable intake among 11 year old school children in a country of traditionally low fruit and vegetable consumption. Int $\mathrm{J}$ Behav Nutr Phys Act 3:41.

Mitchell O., Wilson D.B, Eggers A., MacKenzie D.L. (2012), Drug Courts' Effects on Criminal Offending for Juveniles and Adults", Campbell Systematic Review, Campbell Collaboration, DOI: $10.4073 /$ csr.2012.4

Mohammad A, Madanijah S., 2015.Konsumsi Buah dan Sayur Anak Usia Sekolah Dasar di Bogor. Jurnal Gizi Pangan,10(1), pp.71-76.

Vereecken CA, Keukelier E, Maes L. 2004. Influence of mother's educational level on food parenting practices and food habits of young children. Appetite 43:93-103. 
Jurnal Abdimas Kesehatan (JAK) Vol 1,No.2, Juni 2019 p-ISSN: 2655-9266 e-ISSN: 2655-9218

World Health Organization [WHO]. 2004. Fruit and Vegetables for workshop on fruit and vegetables health : report of joint $\mathrm{FAO} / \mathrm{WHO}$ for health. Geneva : WHO 